\title{
The applicability of Portuguese language teaching in country schools: a case study in the city of Glória do Goitá, Pernambuco, Brazil
}

\author{
Edvaldo Pedro da Silva*1; Maria Lúcia Barcelos Venceslau²; George do Nascimento Leão ${ }^{3}$; Maria \\ José de Lima Silva Andrade ${ }^{4}$; Inalda Maria De Andrade ${ }^{5}$
}

1. Master's student in education with emphasis on teacher training at University Ibero American Foundation -FUNIBER

2. Libras Interpreter Teacher at State Education Network of Pernambuco, Brazil

3. Professor at The Public Network of Pernambuco, Brazil

4. Specialist in educational management

5. Professor at the public-school network of the city of Nazare da Mata, Pernambuco, Brazil

E-mail adresses: edvalpe@yahoo.com.br (Edvaldo Pedro da Silva), marialuciabv2@gmail.com (Maria Lúcia Barcelos Venceslau), georgelion2009@hotmail.com (George do Nascimento Leão), mlimaandrade2011@bol.com.br (Maria José de Lima Silva Andrade), inaldaandrade1@hotmail.com (Inalda Maria De Andrade)

${ }^{*}$ Corresponding author

\section{To cite this article:}

Silva, E.P.; Venceslau, M.L.B.; Leão, G.N.; Andrade, J.L.S.; Andrade, I.M. The applicability of Portuguese language teaching in country schools: a case study in the city of Glória do Goitá, Pernambuco, Brazil. International Journal of Sciences. Vol. 2, No. 2, 2021, pp. $24-38$. ISSN 2763-5392.

Received: 08 15, 2021; Accepted: 08 16, 2021; Published: 09 06, 2021

\begin{abstract}
It is very common to listen that every pedagogy brings within itself a conception of person, of world, of society. Depending on this conception of the person education takes one direction or the other. Education defines what the didactics will be, what are the strategies of the lesson plans, the evaluation system, the relationship between educator and student. In fact, every Pedagogy has a philosophy that gives it the course. Starting for education, depending on the conception of the person who the teacher of the field, has of himself/she will teach in one way or another, will relate to his students in one way or another and all these issues proposed here directly influences the process teaching student's learning, especially with regard to the teaching of Portuguese language in the Schools of the Field. Thus, this research seeks to make comments and considerations about the applicability of Portuguese language teaching in the education of the field, in the fundamental series in Glória do Goitá, through research that will be worked, deployed and presented, showing the values and potentialities of the school of the field, seeking to understand what education is being offered and what conception of education is present in this offer. Moreover, what considerations should be worked on to build a political pedagogical scenario in the field, opportunistic and/or valuing the empirical knowledge of the student.
\end{abstract}

Keywords: Applicability. Education. Portuguese language. Conception.

\section{Introduction}

It is understood as a field, a universe socially integrated with the whole of Brazilian society and the current context of relationships, in this statement, we are not, therefore, assuming the existence of an isolated universe, autonomous in relation to the whole of society and that has exclusive logics of functioning and reproduction. However, we consider that the field maintains social, cultural and ecological historical particularities, which recall it as a reality of its own, of which they are part, including the very forms of insertion in the society that encompasses it.

Although the problem of education is not only in the field, there the situation becomes more serious, because, in addition to not considering the reality where this school is inserted, it was and is systematically treated by the government, with compensatory policies. Therefore, there has not been, historically for the field education system: formulation of specific political and pedagogical guidelines that regulated how the school should function and organize, nor, financial endowment that would enable the provision 
and maintenance of a quality school at all levels and modalities.

"In Article 2 of the Operational Guidelines for Basic Education in Rural Schools. Resolution CNE/CEB No. 1, of April 3, 2002, reports that the school of the field needs to be inserted in the reality of the rural environment, in the knowledge of the community and in the social movements. It needs to be a school that has and works the reality of the people of the countryside. May the earth be a key element, that the culture, the struggles, the history of the field, is a starting point for work in the classroom. (Operational Guidelines for Basic Education in Rural Schools. CNE/CEB Resolution No. 1 of 3 April 2002)

In the official documents on education in Brazil, the rural population appears only as data. These are cited numbers of a forgotten population, they are just quantities or, at most, pejorative references, it is as if the differentiation between rural and urban no longer made sense, so an important step for valuing this difference is to recognize the need for the country school, because a country school is not, after all, a different type of school, but rather is the school recognizing and helping to strengthen the peoples of the field as social subjects, who can also help in the process of humanization in society as a whole, with their struggles, histories, works, knowledge, cultures and their way. Also because of the challenges of their relationship with the field without the formation of social subjects and only schools built politically and pedagogically by rural subjects, they manage to have the way of the field and incorporate in this way the forms of organization and work of the rural peoples.

In fact, we know that in the field schools do not work as they should, in fact schools have a very urban aspect and care about reading and writing, but in a way unrelated to the reality of the rural people, not having reference to the empirical knowledge of the students.

Taking this statement into account, this research aimed to value the knowledge of the different subjects of learning by rescuing their self-esteem and their transforming power from reality. This knowledge can and should contribute to the socialization of power among all citizens or to the creation of power in the powerless by strengthening citizenship.

In the development of the research are relevant and quite significant themes for the strengthening of thought and apprehension of the reader. In general, field education is approached as a macro theme, since it is a worrying topic for those who work and with those who live in the field, due to the fact that the insomnia that is given to rural schools, together with the education of the field, another very opportune theme is the very Applicability of Portuguese Language Teaching in the Country Schools; we will also find in this work a research that shows us a little this context of how these applicates are passed through rural schools.

The teaching of Portuguese language was widely discussed, because it is considered important in the field for the teaching of mother tongue. The school needs to create spaces for the integration not only of the student, but of the entire school community thinking of a local and effective development.

The themes addressed in this research are points of reflection to form a critical mass of children, young people and adults capable of discerning what is right and duty; to know your position and fight as a citizen.

\section{Methodological Aspects}

\section{1 - Research Methodology}

In this chapter, we try to explain a little about the methodological basis that supported the research. The study is part of the field of qualitative and interpretative research, as Stated by Denzin (2006).

In the first section of this chapter, we will discuss the nature of the research; the theoretical-methodological foundation of qualitative and interpretative research, research interviews, and bibliographic research. The second part deals with the nature of the corpus and the subject of the research and interviews. In a third moment, the treatment of the data will be addressed, that is, the development of all data collected in the research phase, both oral and written mapping. Finally, we will approach qualitative research according to the theme: The applicability of Portuguese Language Teaching in the schools of the field.

\section{2 - Nature of The Research}

The theoretical-methodological model adopted in this research was qualitative in nature, we will see below. To carry out the present study, it was necessary to resort to bibliographic research and field research, opting for the research interview, which, according to Gaskell (2002), the interviews allow the understanding of the satisfied, actions, reactions, values, attitudes, in order to end the experiences of the subjects surveyed.

As for the typology of the study, the research/project to be developed is in the scope of field research, since it will be researched to reality, seeking the desired information through on-the-spot observation (schools' field of research).

It is observational analytical, because we will analyze through observation the methodology (traditional or constructivist) applied by teachers. Its time will be transversal because it is developed in the short term, that is, in a single moment, in a single observation. Their findings will be qualitative because it is a small sample intended and selected to work.

\section{3 - Qualitative and Interpretive Research}

Qualitative research is undoubtedly practiced based on the concern not so much to quantify facts, actions, 
phenomena..., but in explaining the paths, the disguises of social relations, considering that human action depends closely on the meanings attributed to it by social actors.

Some factors were very relevant to the accomplishment of the research, the contextualized reports involving the life history of the surveyed, the experiences of and in groups about their daily relationships with people. According to Minayo:

"Qualitative research answers very particular questions. It is concerned, in the social sciences, with a level of reality that cannot be quantified, that is, it works with the universe of meanings, motives, aspirations, beliefs, values and attitudes, which corresponds to a deeper space of the relationships of processes and phenomena that cannot be reduced to the operationalization of variables. Minayo (1995, p.21-22)".

Thus, it is perceived that the qualitative research of this study involved obtaining data with the interviews conducted, but that takes into account the quality of the events that occurred in this teaching learning process, which makes it more important than merely the number of people/students formed in the schools of the field.

As we have previously brought in this research, quality is based on the assumption of valuing actions, life histories, commitments, learning, culture, empirical knowledge, values in general, all from the perspective of forming qualified, competent, efficient and effective social actors, besides worrying about forming a critical mass of children and adolescents who will be inserted in society.

For Luna (2000), in a qualitative research, the choice of the analysis technique has to do with the formulation of the problem to be investigated. Thus, the theory should both suggest questions and indicate possibilities of interpretation, serving as a reference for the results that are being observed.

In the interpretative model, it was necessary to take into account the performance in the search for the legitimacy of the construction of knowledge, regarding the actions related to research, interviews (oral and written) worked between researchers and individuals surveyed; the life history, for example, of each individual can and should be very useful to infer the questions to be investigated regarding the Teaching of Portuguese Language in the Schools of the Field.

\section{4 - The Research Interview}

The research interview represents one of the basic instruments for data collection, from the perspective of qualitative research. In this sense, Lakatos and Marconi point out that in the interview the relationship that is created is interaction, with an atmosphere of reciprocal influence between the questioners and those who answer. Lakatos and Marconi (1993, p. 196-201).

"The main objective of the interview is to ensure information from the interviewees, in a safe way, about their experience during the activities developed in the classroom, in the community and in family relationships in general. About this resource, Gil states that the researcher can ask questions to the interviewee in order to obtain data that interest the investigation and that the interview is a form of social interaction and a form of dialogue, in which one of the parties seeks to collect data and the other presents itself as a source of information. Gil (1987, p. 113)".

\subsection{1 - Nature of The Corpus and The Subject of Research}

The research was based on oral, written and bibliographic data generated in interviews with elementary school students and teachers who narrate their life stories, involving moments when they start and assume their role in the construction of an integrated and sustainable local development. The choice of research subjects arose after the need to identify how Portuguese language teaching would be approached in the country schools; if it followed a fixed rule or followed the specificities of the field, with its customs, cultures, experiences, etc.

\subsection{2 - The Subject of Research and Interviews}

The subjects interviewed in this research are students and teachers of field education, especially from the municipality of Glória do Goitá - PE, who work with Elementary School I. The place of the interview, the schools of the field in Glória do Goitá, was chosen so that it would give us more security, availability and reliability for the development of the work, in view of the research objective: to observe, understand, research the teaching learning process in the applicability of Portuguese language teaching in the schools of the field.

The studies/researches were developed in two ways: on site and bibliographic, in view of the need to study and research theorists involved in the theme. One moment with the students and another with the teachers, both in writing and oral form, but all in a discreet and professional way to the point of not embarrassing the interviewees. The oral ones were recorded by a digital voice recording device, which will be used for analysis and then written and transformed into considerations by the interviewers.

All interviews were conducted in February 2015. For the surveys and interviews to be conducted, it took two moments. At first, we only played the role of observers: we observed and talked to the faculty and students of the schools, as well as the school community, all talk in a very informal and relaxed way so that both parties would be comfortable and that it did not seem to be something imposed. At another time we went to schools' fields of study for the application of the questionnaires to be analyzed next and with this forms the research developed.

\subsection{3 - The Speech in Interaction and Coherence}


In order to analyze the oral data, it was necessary to transcribe them for study purposes. The appropriate methodology when working with orality or speaking in interaction and coherence is to take into account not only an investigation of the reports by the reports, but also the forms from the placements of the researched, the feelings of each one when explaining their ideas and experiences about what is worked and how the Portuguese language is worked in the whole, in an interdisciplinary manner.

It is also to observe in the speech what is cultural is approached in the school of the field or even what is taken into consideration about the experiences, experiences, empirical knowledge of the community taken to the interior of the school. All this is part of this observation of orality that should be in interaction with others and coherent from the point of view of the experience and everyday reality of the school and/or the school community.

\subsection{5 - Data Processing}

In addition to all the concern stores about the data collected, a specific way of working them and maintaining them as a study tool was also articulated. The research itself went through four stages: RESEARCH, UNFOLDING, RETURN AND EVALUATION. In fact, when we talk about research there are a number of steps to be developed; based on the assumption that it is not a research with a specific purpose of return directly, only a few steps were needed: the research itself, then there was a study to unfold the data collected written and oral, the return through tables, graphs, etc. only to a specific group, in order to evaluate the performance of the researchers, and finally an evaluation of how the work was done during the research period.

\section{Theoretical Foundation}

\subsection{Historical City of Glory do Goitá/PE}

The occupation of the territory of the municipality was initiated by farmers, directed by David Pereira do Rosário, who established residence in Sitio Lagoa Grande, embedded in a part of the lands received by donation from Duarte Coelho's granddaughter. From 1760, with the construction of a small prayer house, the town began to attract many visitors. In a short time, the nucleus became a village, called Gloria do Goitá, of the Saint chosen for the house of prayer and Patroness of the city.

The word Goita is of Tupy origin, name of the river that is part of the hydrographic system of the municipality. Goitá is a corruption of "Gua -ta", which also translates from Tupy as "flour stone" or "low stone", stone to break corn to make corn meal and cassava to make flour, a translation that we are led to admit it by the happy coincidence of the predominance of indigenous crops such as corn and cassava.

Glory of Goitá is rich in tales and legends. There is a neighborhood called Capuchin due to the Capuchin friars of the Monastery of São Bento de Olinda, which had bought, inherited and received by donation, three thousand bouts of land of sesmarias, on the ribeira do Guaytá or Goitá, as it is known to this day, in order to make the catechesis of blacks.

These friars built a large dam where two crosses are found, one large and one small, due to a legend told by the ancients. In this weir came groans that haunted the population, who thought they were feathered souls. Why they called the friars of the monastery to unravel the mystery, because sometimes there was a cry of a child coming from the dam.

So, the friars made a mission around the dam. They asked all the women to be around with a third praying that the feathered soul would reveal itself and calm down. That's when a snake came out of the weir, with a child's cry. Then the friar revealing that he was the feathered soul, asked the snake to seek his mother, among the young women. Then she prostrated herself before her mother. Soon, the friar asked her mother to breastfeed her daughter. When she was being breastfed the snake became disenchanted, turning into a beautiful girl. Soon after, the two of them died. That's why there are two crosses in this place.

The municipality is located in the transition range between the coastal trays and Borborema, and the relief is formed by a surface elaborated in crystalline rocks, disseized in the form of hills with convex slopes. The climate is tropical and semi-arid. The average annual temperature is high (about $25^{\circ} \mathrm{C}$ ), resulting in a warm climate throughout the year.

District created with the name of Gloria do Goitá, by provincial law no. 38 of May 6, 1837, subordinate to the municipality of Paudalho. Elevated to the category of municipality with the name of Glória do Goitá, by provincial law no. 1297 of July 9, 1877, dismembered from Paudalho. Installed on January 10, 1878. Elevated to the status of city and headquarters of the municipality with the same denomination, by provincial law no. 1811 of June 27, 1884 .

Its population is approximately 28,000 inhabitants, with an electorate of approximately 20,000 . The municipality is $69 \mathrm{~km}$ from the capital - Recife. It is part of the cities that integrate the Capibaribe Basin, located in the Zona da Mata of Pernambuco with an area of $231 \mathrm{~km}^{2}$, is limited to the North by the municipalities of Feira Nova, Lagoa de Itaenga and Paudalho; to the south by the municipalities of Pombos and Vitória de Santo Antão; the municipalities of Limoeiro and Passira. The municipal head office at $150 \mathrm{~m}$ altitude has its geographical position determined by the parallel of $8^{\circ} 01^{\prime}$ 11 ", south latitude, at its intersection with the meridian of $35^{\circ} 17^{\prime} 35^{\prime \prime}$, west longitude.

There are several attractions and sights appropriate to agro tourism practices in the municipality: mamulengo, maracatu, coco de roda, cavalo marinho, capoeira, ciranda, Santuário de Mãe Rainha, Campo da Sementeira/SERTA, Fazenda Colinas do Campo, Fundação Pau - Brasil, Praça de Eventos, Monumentos Históricos, Cachoeira de Canavieira, Praça Cristo Redentor... It also has an educational offer 
composed of 38 municipal schools, 02 state schools, 03 private schools, several schools linked to associations and 01 daycare.

The municipality is predominantly rural, and therefore 88 sites (rural area), this means that most of the population is concentrated in the rural area, in the countryside, otherwise much of the urban population travels to the rural area to develop rural, agricultural activities during the day.

\section{2 - Field Education}

The school in the Brazilian countryside appeared late and was not held responsible by the State. Until the first decades of the 20th century, it was destined for a privileged minority, although Brazil was and is a country where agriculture prevails. Even with all this potential the schools of the field, were not mentioned in the texts written in education, in fact it was a dismay for the people who directed education

This panorama conditioned the evolution of school education leaving us a range of fragility in the functioning of the school of the field, for local, social, personal development, etc. As for example: human elements poorly prepared for pedagogical development, a precarious infrastructure, geographically schools are not favorable to work, salaries lain, is one of the strongest points, the organization of the curriculum completely decontextualized from the reality of rural students.

Until then, field education has always been treated with compensatory policies: projects and programs that began and ended with government management, and never a school with policies that thought to work the reality of the rural population.

It is important to be clear that field education is not just schooling. It is larger than the school, since it is involved in the movement and organization of the people. Schooling, for example, is very important, but it is simply one of the times and spaces of human formation the constructive process in education permeates initiatives, such as:

Formal education - it is that schooling aimed at different levels of education (kindergarten, middle, professional and higher school) being articulated by the public, private or community education system.

Non-formal education - are initiatives aimed at community, productive, political, cultural, trade union and religious organization; most often articulated by social movements, trade unions, NGOs, civil society entities, etc.

Informal education - the whole formative process occurred in the family, in the communities, in the groups of friends, through means of communication, etc.

Despite being a little differentiated from each other, but when thinking about development, a participatory management committed to the teaching of mother tongue within the school, in the and in the field, we should think of them in an integrated way, with thoughts, plans and actions aimed at a better quality of life.

When talking about popular education, one immediately thinks of the most marginalized, suffering and poorer population swells that take hold of a new knowledgeinstrument, which can be used directly in the achievement of the social, cultural and economic objectives of these popular layers. It is a new knowledge, because, whatever the current situation of a popular group, it has its knowledge inserted in its customs, experience and practices; whether at work or in daily life, in their culture, in social relations or even in their ideology, that is, their own way of living, although coming from other social classes.

To all this mixture, involvement, traditions, experience, customs give the name of popular culture. Some very strong ideas are together with popular education: the true values of the people are their own values, which is inserted their way of life, with their customs, with their understanding of life and society; another very important idea is that these values are not enough for the people to articulate themselves to society to potentiate or articulate their interests and rights.

Taking into account these values, these ideas, it is perceived that the projects, the programs through field education should meet the needs of the people of the field, and not of the projects focused on the interests of another social class. It should start with the very set of popular values and knowledge.

Given all this explanation, we may not yet know what country education is, or popular education. We do know that no one escapes education. At home, in the street, in the church, in school, in the countryside, in the city, we are all involved, so that, we learn and teach, we know and do, we are and we live together. For all this to happen we need to mix life with education.

Education is a social right and not a matter of market. We can associate field education with various meanings, one of them is education that recreates the field, which renews the values, attitudes, knowledge and practices of belonging to the land. It works the self-esteem of the rural people recreating the identity of the subjects in the struggle and struggle as a social right, with inclusion in the organization and social planning of the field, finding conditions and solutions for successful, reliable and productive rural development.

Society generally needs to commune in the certainty that the city is no better than the countryside, and from this understanding establishes concepts the organization and structuring solidarity between field and city, from power, political management, economic production and knowledge.

The field is considered, understood as a rich and diverse space, at the same time product and producer of culture, it is this diversity that makes it a space of creation in the new, tangible and intangible, creative, and not when we reduce it as a place of economic, social, cultural delay etc. Where we have a mass of just matuto, poor, needy, poor. The countryside is above all a cultural space.

Society must understand that country education has subject who conquer stories, defend and fight for society, who dream of feet on the ground, have names and faces, carry with them stories of past generations that strengthen the 
basis for their daily struggles.

The educational system, and especially the school need to understand and take seriously all empirical knowledge of parents, students, communities, rescuing them in classrooms through debates, lectures, visits, so as to ensure the knowledge produced in the various areas of knowledge. Perhaps this knowledge alone does not make such a difference, but when added to the cognitive knowledge of the school becomes a new instrument of weight and knowledge for the change and breaking of many paradigms encastelados in the community.

Above all the teachings and goals the schools of the field must excel the elements that permeate and articulate the curricula in the schools of the field, they are: the earth, the environment and its relations with the cosmos, democracy in all areas (management, commercialization), resistance and renewal of struggles and physical spaces, as well as social, political, cultural, economic, scientific and technological issues.

The school should think of the field subject as a reference with specialties and insert it as a subject of transformation. For this, the rural school educational project needs to be from the countryside and in the countryside and not to the countryside.

Research is a very significant tool for rural development; it should be inserted in schools to provide students with the ability to think, to reason to interpret more logically.

The school needs to be where the subjects are, where there is a subject, there is transformation, there is knowledge and the school needs to insert itself to the reality of the community to think together of a model of education that can meet the needs of a people; after all knowledge and education does not happen only in classrooms with chalk and blackboard. As Paulo Freire states "In the shadow of the hose is also educated" (July 2001), interpreting this quotation, each individual brings with it a range of knowledge and should be valued with all its diversity of knowledge.

The themes to be worked on in the school should be linked to the world of work, to the development of the field. Thus, we will have general contents (Mathematics, Portuguese Language, History, Geography, etc.) that students learn in practice from the reality where the school is inserted.

The methodology should also be focused on the reality of the field, rescuing the materials available in the environment, knowledge that parents, students, the community, technicians, teacher, teacher, school faculty, in general, have about the various themes to be addressed.

The interesting thing about this constructive process is that the teacher is not the only builder and mediator of knowledge, although it has a fundamental role in the educational process. Working like this, we are rescuing the riches, experiences, stories of a people who have their roots focused on the countryside, for the land, for rural production, all with a very innovative procedure (classes in the garden, excursions, interviews, meetings, dramatizations, observations, etc.) through alternative and scientific resources (books, newspapers, magazines, videos; nature itself: rivers fields, saws etc.) we can use as pedagogical spaces (the community, forests, cerrados, swiddens, mills, flour houses, health posts, historical movements, squares, public agencies, etc.), building an innovative practice and appropriate to the reality of the field.

How will a child learn mathematics by picking chicken eggs in the chicken coop, or rather: picking fruit, even better: counting the members of his own family? And the production of text, the famous school writing, through situations experienced by each student with their family members or communities; biology or science through the little kitchen gardens in the backyard, collecting the chives, lettuce, coriander and the animals involved in the leafy. Is it cool to learn like that? Or is it best to learn from a textbook, often with themes and subjects focused on other realities?

According to the Operational Guidelines for basic education in rural schools (Article 3,6 and 7) states that:

"The municipal system should offer early childhood education and elementary school in rural communities, including for young people and adults; that is, the law guarantees the permanence of the school in the field, without having to have every child be moved to the headquarters of the municipality to be able to attend the School. (Operational Guidelines for Basic Education in Field Schools)".

This same reference to Law 9394/96 refers; let's look at some indispensable topics for an effective field school. As for the school organization, as stated in the (Article $7 \S 1$ and 2) the school can form multi-serial classes, alternating, the calendar goes according to the reality of each community, provided that it fulfills the workload of 200 school days as guaranteed by the LDB; these days being developed within the room or in alternation. In articles (10th and 11th) we find democratic management, where the father, mother, and the entire school community have the right to participate in the discussion of macro school management, through municipal education councils.

- School board

- Management committees: school box, lunch, FUNDEB.

- Education conferences.

In the Educational Proposal to support sustainable development - PEADS, as Abdalaziz de Moura states:

"All education has to be environmental all disciplines are environmental, both Portuguese as mathematics, geography or history, as all education has to take into account plurality. Everything at school should stimulate cooperation: texts, calculations, distribution of tasks, values transmitted, etc. Now establish environmental or cultural education as if it were a specific discipline and give Mathematics or Portuguese as if they were not 
environmental does not fit in PEADS. (MOURA, 2003, p 56)".

Interpreting some of Paulo Freire's lines, we need to create the school that is adventured, that marches, that is not afraid of risk so it refuses immobilism. The school you think about, where you act, what you talk about, what you love, you guess, the school that says yes to life.

Creating spaces is, above all, creating opportunities for constructive participation of the student in the educational process. Opportunities for the integration and exchange of knowledge and experiences between educator, student and school community in the construction of a mechanism for the development of the school, community, etc. The educator needs to be an actor, needs to act in several ways to develop a successful work, a pedagogical construction that is efficient and effective. You need to have and master personalities:

\section{The educator as a leader}

What is educator as a leader? We have three alternatives for educational action in the learning process: non-directivity - works a more liberal pedagogy, based on the notion of freedom as non-restriction. Freedom, especially in the creation of norms.

Another alternative is the directive, which the educator needs to train himself to work the behavior, the attitudes of the student coordinating and articulating the variables that favor this behavior. While the non-directive posture underestimates the role of the educator, the directive posture overestimates the role of the educator and underestimates the role of the student. Nor is it a posture to work with the personal, social, economic development of a so needy public, which is the population of the countryside.

We share in the certainty that for a constructive and acceptable process, fluid with property will be a democratic directivity, where the educator is the driving force for the direction of action, giving the student opportunities to manifest, ask, interact and influence the course of events, to be heard, to be an actor in the formulation of objectives.

\section{Educator as organizer}

The educator is responsible for his work, for time, space, activities, etc. Having the educating as an intermediary of the achievements of the actions. When the educator chooses an activity, with objectives, methods, he is not simply making the choice of a method of action - he is making a choice of himself, as an educator, human being and citizen, that is, this choice is political and ethical. And that's a responsibility we shouldn't walk away from.

\subsubsection{The educator as the creator of events.}

The true role and function of the educator must go beyond the classroom, we have to be innovative and create events, providing opportunities the student to investigate and research their surroundings. For these events to become real and conducive to the community, it is necessary for the educator to organize the material bases, making clear what is the school of the field and in the field, what the role of the school for local development, etc.

Another important thing is to work relationships. In these relationships are involved the experiences both in classrooms and in families and in the community itself, hence questions arise regarding the person of each member mediator of the learning process: educator $\mathrm{x}$ students $\mathrm{x}$ parents $\mathrm{x}$ friends. And with this process worked, comes the most important: the organization of the representation of the process, that is, what is the educator, the student, the family in the elaboration and execution of planning for local development? As Costa says - the teacher as an educator:

"The organization of people, time, spaces and materials to reproduce events capable of directing the educational process in a given direction is what we call the grammar of life. The grammar of life has been the context and the guiding thread of the educating relationship for a while. (COSTA, 2001 pag. 133)".

To assume its role in this space the educator needs to exercise is what we call dialectical proximity distancing; experience as close as possible the personal and social circumstances of their students, by distancing themselves, to move away from the plane of critical thinking, to perceive how their acts are inscribed in the concatenation of events.

The educator ends up being motivated and this motivation with the meetings and with the work reinforces the idea that one of the ways of teacher education is that aimed at the reconstruction of the meanings of their professional action. The educator ends up meeting with what he does and when it happens, he truly commits himself to the cause he develops, identifies deeply with it, attributing to it a sense of belonging, which is part of his life.

As proof that I explain, follows some illustrative statements of professionals committed to the work, according to NÓVOA and KRAMER:

"This job is so important to me. I'm finding myself. I see that my students are creating. I can introduce myself, now I'm rethinking it." "We are being valued as professionals", "The important thing is the exchange of experiences. I see a greatness of exchanges, of techniques that really enriches us. We communicate with each other. That's pleasurable." (NÓVOA, 1991 and KRAMER 1993).

Leader, organizer, creator. The responsibilities of the educator are immense and complex. It takes attention, dedication and constant involvement in the educational process, in the classroom and outside it. Face such a challenge, in a planned way and who want to be recognized as educators, builders and facilitators of the process, able to sensitize the student from the field to the field according to 
his expertise focused on the mobilization, improvement or construction of an Integrated and Sustainable Local Development - DLIS.

Creating spaces after all is not allowing students to be "spacious" in the most popular sense of the word the ideal is to know. How to open paths for the construction and consolidation of new learning spaces, without losing the conduct of the process, without losing the thread of the strain and the notion of limits.

A simple but welcoming suggestion would be for the educator to create new spaces for educational work in his school, a concrete space. Create! Involve students at all stages of the project. First, research what your school doesn't have and improve everyday life if you had: A mural newspaper? A vegetable gardens? A gymkhana? A sports championship? A poetry contests? Music? A task force to clean up the school spaces?

Then organize the volunteers for the development of the project, including the school community. Plan well the action to be implemented: what to do, how to do, with what resource, in what timeframe, for what purpose? In the end! Let's get to work! This is how new spaces are being built! After all, educating is to create, realize and validate coexistence, a particular way of living together and in this coexistence, men build the tools and tools that rebuild man.

\section{3 - The School We Have and What We Want for The Teaching of Portuguese Language}

The school is a very important institution, in its people develop different relational models, build knowledge, develop habits. It is a space for growth both for the student and for the educator himself.

For Arroyo (2004), school and school knowledge are a man's right, but this knowledge has to be inserted with the reality of the community.

You don't have to look too far to find the school in the countryside. One issue that runs away from the responsibility of the school is the lack of attention to the personal and social development of the student.

Although the school is considered the institution capable of promoting the social equality of students, the school we have today is a cultural result of the end of the 20 th century where it was reduced only to teachers. That's where teaching becomes everything in school, what happens? The answer lies in each school we find: lack of structure for the well-being of children; there is an absurd precariousness in schools; what does a teacher do without materials suitable for teaching-learning children? Why only urban schools have to have, good wallets, piped water, good coverage, tv, video sound, energy, etc.?

This is a bit of the schools we have in the field, in fact the students of the field are seen as poor, poor, the needy, the matutos and anything enough to meet the needs of these actors. Above all, the leaders of the three spheres of government lack the understanding/awareness of the leaders of the three spheres of government for education in rural schools.

The most obvious thing is to have children in these schools, most of them discredited; because the scenario of the institution they attend is precarious. The discredit is not only of the children, but of the community where the school is inserted.

There are some of these schools' teachers who think differently, who seek to change the school scenario, so that the student is part of the learning and accepts himself as a driver and builder of the process; that is, innovative educators, constructivists; with mobilizing attitudes. As Boff states, "attitude is a source of deeds." (Leonardo Boff; 1998). If attitude is a source of acts, assistance is the attitude of being there to watch, to care. It is that careful posture, attentive to the other, the result of responsibility. Costa brings in one of his explanations the following:

"If I had to think of a school for today, I wouldn't think it was reduced to the size of cognitive teaching. I have to think of a school that works the cognitive, the affective and the pragmatic, a school of reason, emotion and action. I must therefore think of a school for the entirety of the being of the student. (COSTA, 2001.p.33)"

The school needs to be a community of meaning, where the cognitive works, and the pragmatic, a school of reason and action. A community school where each one - director, teacher, assistant, employee is an educator. Each doing different activities, but sharing the same motivation, the same goals, the same purpose and the same commitments. Instead of the exhibitor teacher, we will have the consultant educator of knowledge-hunting students. After learning to read, write, enter the education module we propose.

Instead of having only knowledge and reason, the education system should have three sources of light: reason, emotion and action. This is the three-point meeting that will preside over educational evolution in the 21 st century.

In this evolution the student will be prepared according to the 4 pillars of education, which we can consider the foundations for a new pedagogical humanism: personal competence (learning to be), relational competence (learning to live together), productive competence (learning to do) and cognitive competence (learning to know). On top of these 4 pillars is that we should articulate a pedagogy for the 21 st century.

A school based on education: knowledge, values, attitudes and skills using research as a tool - a driving force for discoveries in education. A school for a culture of peace, a culture of respect; a school not only concerned with transmitting content, but that works according to the paradigm of human development.

A school that has its critical, thinking, integrated and interacted with community social events that serves to support its learning and pedagogical constructions, whether 
in Portuguese, Mathematics, Sciences, textual production, etc.

\section{4 - The Teaching of Portuguese Language in The Schools of The Field and The True Role of The Educator in This Pedagogical Political Scenario}

The teaching of Portuguese language in rural schools will also take, according to the process of training and continuous improvement of teachers of the basic education school, especially in the field. From the critical point of view, it must articulate the educational system organically, therefore it demands the elaboration of a politicalpedagogical project that permeates the three levels of education, allowing to change the quality of the school, both in terms of content and in methodological terms in the perspective of a process of democratization integrated in its political, pedagogical and technical dimensions.

Educators need to be prepared to act in the scenario proposed to them. That is, it is necessary to know, to have a knowledge of the world, of what it will do, without showing, or without clashing with the various prejudices experienced and impregnated in the rural population, including by themselves, due to the cultural tendency of discrimination of the countryside, of the rural.

It is known that in the country, several congresses, symposia, seminars are articulated in the intention of improving the quality of education, and with this concern comes also the Teaching of Portuguese Language, especially when we talk about its applicability in the field. It's easy and it's hard. What's the talk of the country people? And the most interesting: how is this talk by society? There is a strong prejudice with speaking, acting and writing of our rural population. As Bagno says:

"Linguistic prejudice is quite clear in a series of statements that are already part of the (negative) image that Brazilians have of themselves and the spoken language. This way (BAGNO, 1999. p. 13)"

Each region, each population has its paradigms, has its linguistic varieties it is up to the school to work methods, ways of integrating with this "encastelada language", but for the rural population is the correct language, because from it come the pacts, the initiatives, is that flow the communications of a people, the referrals the decisions etc.

"Since the beginning of the 1980s, Portuguese language teaching at school has been the center of the discussion about the need to improve the quality of education in our country. In elementary school, the axis of discussion, with regard to the school franc, has been the issue of reading and writing. (PCN - Portuguese language - 1997. p. 19)".

In our view of the Educational System, the MEC will always have this concern and above all an index of repetition, indiscipline, etc., very presenting education, because it follows a curriculum aimed at meeting, most of the time, the needs of the south and southeast.

When arriving in the northeast, and even more, in the rural interior-schools, this curriculum is not enough to awaken the learning of the students of the field, since it finds a completely different reality from what it prays in the curriculum. It would become easier and more acceptable if students could choose what they want to study.

It's hard, it's hard to accept by force, something I'm not into, that I don't want, and that's exactly what happens to our student body. Today the student read by imposition of the school and/or family, thus no longer being a pleasurable reading or a pleasurable act.

When we leave to teach the Portuguese language is no different; in addition to the curriculum, professionals are not prepared to deal with the various situations that occurred in the field. There are exceptions with some educators, that is, educators who live or who know the stories, customs, paradigms of the field are part of the student's learning process, why not say the community, but the one who goes to rural schools only pass on information, that's where the concern is, because there is not always a concern impregnated when doing, teaching for rural development; so that it will only teach the student to listen, to read and write, and forgets the essential: mobilize the student to read and write his i, his reality in his surroundings, be critical, question the unquestionable, problematize problems.

What's easier? Does the student write an essay about the beaches of the coast, or a river near his community? It is logical and convincing that to talk about what we know is to feel that you have the piece, author of the action, etc. This was a clear and objective example, even hilarious, but it is nothing less than what happens in many rural schools. The teacher gives the subject ready and finished, does not create or does not awaken in the student the habit of asking and researching.

The Portuguese language can and should be worked on in the process: listening, doing, hitting, err, trying. Why not teach Portuguese in the school hours? Why not make sense of family? And with sense, work History, Geography, Portuguese, Science, Mathematics and etc.

Why do our students have to know the World Wars, the Nile River, the entire Northeast, but are not sensitized to know the conflicts in the community associations, the river and/or the dam that is close to their home, do not know the community, customs, culture, the oldest peoples, the history of their family of the community?

There is no other way to appropriate these issues unless through the school, being responsible for the psychosocial construction of the student, all this knowledge are sources for the teaching of Portuguese language in schools. And then we do not run the serious risk of school dropout, because we are talking and working something that children know they have property can explain equally with the educator, even if it is in his way, with his experiences.

They feel valued, even better because all empirical 
10 Silva, E.P.; Venceslau, M.L.B.; Leão, G.N.; Andrade, J.L.S.; Andrade, I.M. The applicability of Portuguese language teaching in country schools: a case study in the city of Glória do Goitá ...

knowledge is being taken into account in the perspective of maturing cognitive/scientific knowledge.

The important thing is to teach Portuguese language optimizing the knowledge that already exists, because at home, at school, with the use of radio, television, conversation a generation passes to another knowledge and knowledge producing more integrated people. The school needs to prepare the student, whether child or young, to pass through the pillars of being and living together to get prepared in doing. It is also worth mentioning that learning and teaching is not a task only for the school.

The family, daily coexistence, access to the media and the exchange of experience with the elderly are strong means of education, production and dissemination of knowledge. When we refer to social knowledge, we are talking about the set of knowledge, practice, procedures values, feelings and rites that a society deems necessary for its survival and circulates among its members: children, adolescents, adults, men and women.

It is up to the educator, especially of Portuguese language, to improve these concepts for differentiated and constructive teaching be it textual production, grammar. The important thing is to consider the values that circulate in the community.

\section{5 - The Education of The Field and The Non-Typical Standards of The Field School}

It is known that the practice of teaching-learning, especially in rural schools, follows a certain pattern, which is not typical of rural education. The countryside, the rural is only the middle and is not always part of a procedural construction of learning and knowledge. This makes us go back, a little to the past, and try to understand that: we always work things (education, health, agriculture, social, etc.) to change people, today, the opposite happens, we must work people to change things.

And this is because many professionals believe that the easiest way out is always the best. Or, because someone with a hierarchical power proposed, is always the best, is unquestionable, is untouchable. And ends up forgetting their potentials, not giving value and belief to the skills and abilities of the public who develop their activities.

All this together, makes the education of the rural field pass, so a certain conduct and obstacles that sometimes privileges sometimes prevents the appropriate/appropriate educational process for rural schools.

The first obstacle is related to a historical posture of absolute disbelief regarding the possibility of individual or collective action. About the place in this aspect, the usual behavior is to drive away to the public authorities, in a certain abstract way because inaccessible, the responsibility for the fate of their place, the pattern of man's relationship with his place, depends less on the knowledge of environmental, social community problems than on the sense of collective about this place.
The second obstacle refers to the force of the habit imposed by the routine, by its cyclical and repetitive times that cloud the ability to perceive and read the environment in this regard, environmental perception is mediated by signs that translate uses, habits, beliefs and values, not being explicit within the verbal logic. Developing the exercise of perception of the field, therefore, means penetrating the language of the place from the personal or collective history of individuals and/or a group.

The third obstacle is related to the fact that the naturalistic idea increasingly acquires centrality in discourses that are produced and circulated in numerous institutions and, especially in mass communication agencies. An idea to which nature, the field are seen as harmonic, autonomous in relation to human existence.

The sum of the environmental obstacles pointed out requires the development of two different levels of action: strangeness and (re) knowledge of the place. This double movement must take place through situations that lead individuals to be surprised by their place and before themselves, transforming both into space powers of renewal.

The actions of the MEC should be appropriate to the deliberations of a national education forum that could define from broad national debate, the political-pedagogical guidelines the educational priorities to guarantee resources for all levels of education and, above all, for the application of each discipline according to the scenario to be worked. This would give schools greater, safer stability in search of school autonomy, and this is fundamental in two distinct perspectives that express distinct problems and which is intended to improve.

The first of them recovers the rationality derived from classical liberalism and associate's autonomy with freedom, that is, autonomous management is one that is exempt from intervention and control of political power, being directed by individual consciousness or the institution.

School management understood as synonymous with the administration of an organization that pursues certain purposes is immediately associated with the image of a company and evokes the figure of the director, mainly as manager of the functioning of the school.

The second is an ecological perspective whose idea of autonomy is constructed as a synonym of self-organization, inseparable from the ideas of ecological dependence of the environment in this case, the collective participation of the different educational actors in the school's planning processes is called for management.

The construction of institutional identity, democratically speaking of each school in the field will then be the result of the autonomous organization of the bureaucratic body closely linked to the interests of the community. According to Tedesco:

"The good performance of these students does not depend on the character of the institutions, but on the dynamics there of the greater or lesser institutional 
identity associated with the degree of autonomy of schools to define pedagogical styles of action. (TEDESCO 1998. p 29)".

It is interesting to look at the difficulties that parents face to get involved in school activities, sometimes schools encourage the presence of parents in administrative and pedagogical management, as a mechanism for monitoring the fulfillment of educational performance, but they do not identify themselves as interlocutors instructed enough to intervene in this type of issue.

The arguments about the difficulties or lack of interest of parents in participating in the collective affairs of the school for the construction of learning, commonly used by teachers and principals, are quite reckless and seem to reveal a distorted view of the community. The most obvious impression is that the community does not want to participate in the school process.

According to Vitor Paro (1997) in one of his research espreeds conducted in public elementary schools, the most important aspect of this resistance is the fact that there is almost no public-school identity with the problems of its community. According to the author, the criticism of community members to schools is that the reciprocity of action can be summed up in the question: "If the school does not participate in the community, why will the community participate in the school?" (Paro 1997.p 37).

In the face of every explanation, we are certainly tempted to ask: what teaching model should be adopted? This question has no a priori answer, nor an answer that can be qualified as right or wrong. This is because there is no model for teaching right or wrong, identified by professional A or $\mathrm{B}$, but propositions that reveal rationality, perspectives, contexts, experiences and distinct interests.

All approaches emphasize the need to make their own decisions for learning, taking as reference the world knowledge of a population, a community, etc.

\section{Presentation of Results}

\section{1 - Approaches to Portuguese Language Teaching in The Schools of The Field in Glory of Goitá}

We will discuss below a research conducted in some rural schools (see annex) and that brings us some important data for the educational leap in the teaching of the Portuguese language in the schools of the countryside.

A priori we organized pedagogical forms for the student, then an analysis was performed from the data. To perceive a good relationship between educators and the student and this is an important role in and for the exchange of knowledge in this process teaching learning with regard to The Teaching of Mother Tongue. According to the students, the Portuguese language is taught taking into account some values of field education, with students as builders of knowledge. Another important data is the space, the teacher contextualizes the class in diverse places and not only in the room, and largely collective (the whole room) and in a group (small amounts) the interaction and integration of the student is perceived with this.

For their personal, social, economic development, it is more important to live with the different, group work helps the child to have an equal look at the schoolgirl. According to Arruda:

"The task of teaching is concentrated in all components of society, the school or classroom, it is not the only place that students can learn so educators should not be focused only on the rooms in the relevant spaces of learning. (Arruda, 2001. p. 46)".

We also work on the production of text with the students, below are some texts such as those written by the students. The question was for them to weave a short text about THE IMPORTANCE OF STUDYING IN THE SCHOOL OF THE FIELD and also HOW THE TEACHER APPROACHES / WORKS THE PORTUGUESE LANGUAGE IN THE CLASSROOM? Below are some texts produced by the students, in full (so the "grammatical errors"), of the school field of study:

"Yes, we do not study agent will not you a good future in life so we should study for a good future". (4th year student)

"Without the study no one knew anything. With the study people learn to read and write it is very important for everyone just because it is poor will not study with the study we can grow in life the greatest weapon against violence and the study we can end with violence studying to be able to change everything". (5th grader)

"I study to be people in life. Without the study we're nobody. I need to get a job and get to work. And then with job agent can buy our things" (5th grader).

"Since I was a little boy, my father taught me how to study, because it is with the study that we can achieve a better future" (4th grade student)

"The teacher teaches text of the things of our daily life, becomes easier, we work like this. We can do better, she talks a lot with us, it's important to teach us at the country school. With the texts of us she enjoys and teaches Portuguese" (5th grader)

It is amazing how strong these children are in speaking and writing; they are owners of space, and the best: owners of words; for them it doesn't matter if they're right or wrong what they wrote. After all what is right or what is wrong for a child from elementary school I to 5th grade?

Why not ask what is right and what is wrong for us mediators of the educational constructive process? For these children the important thing is communication, knowledge, knowledge that they are passing on to paper through pencil and to day to day through their actions and words.

Let us follow the unfolding of the research according to each questionnaire answered by the students in relation to the experience in the classroom and outside it. 
12 Silva, E.P.; Venceslau, M.L.B.; Leão, G.N.; Andrade, J.L.S.; Andrade, I.M. The applicability of Portuguese language teaching in country schools: a case study in the city of Glória do Goitá ...

Table 1. Teacher-student relationship in the classroom

How do you consider the relationship between teacher and student in your classroom?

\begin{tabular}{ll}
\hline Regular & 00 \\
\hline Good & 03 \\
\hline Great & 43
\end{tabular}

Source: Search data

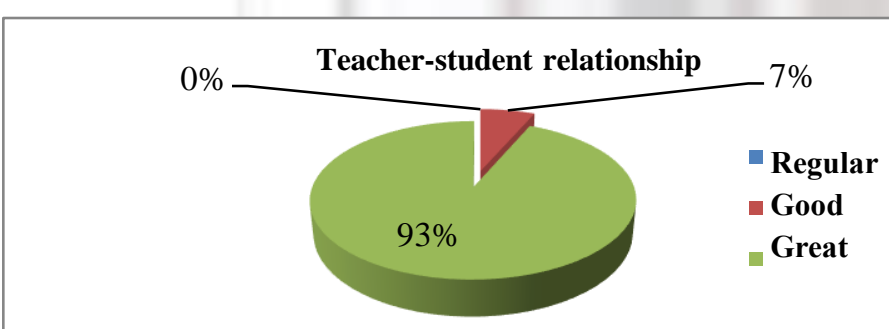

Figure 1. Teacher vs. student relationship. Source: Search data

It was interesting how the texts led us to understand, about the concern of children in the construction of the project of life, peace, of the future, all these are reflections of the values worked in the school reflecting the community. In the process of being worked directly from this context, it is necessary to return to the PCNs when they state:

"The purpose of LP teaching is to expand the possibilities of language use, it is assumed that the capacities to be developed are related to the four basic language skills: speaking, listening, reading and writing." (PCN - LP 1997. p. 43).

Table 2. Teaching Portuguese in the classroom.

How do you evaluate Portuguese language teaching in your classroom? Why is that?

\begin{tabular}{l|c}
\hline Regular & 00 \\
\hline Good & 10 \\
\hline Great & 36 \\
\hline
\end{tabular}

Source: Search data

$0 \%$ Portuguese language teaching assessment

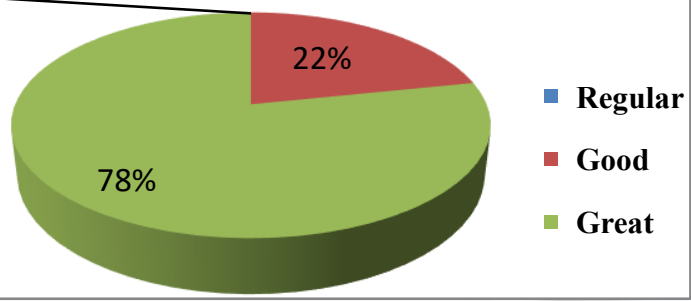

Figure 2. Teaching Portuguese language. Source: Search data

(Conversation with the interviewees, systematized by the interviewers about why this evaluation of Portuguese
Language Teaching in the classroom).

"Because the teacher tries to teach listening to us brings subjects that we know and can talk about what she brings, and it makes it easier for us to learn." 5th year student

This pedagogical didactic context leads us to a reflection and turns to the new pedagogy, where the educator ceases to be the center, giving space to the student. The teacher ceases to be the transmitter of the contents, being a facilitator of the teaching learning process.

The programmatic contents are now selected in groups, dynamics, research. Which are priority tools for this constructive and innovative process for the student's life, which is the importance, the appreciation, the emphasis on the contents related to the daily life of each or every group or even the community in general.

We decided to select texts from the 4th and 5 th grade classes, because they are students who are more involved in textual production and that this production is more involved in the demands of the family's daily life. In the field we do not find the infant/juvenile student outside the housework. It is a task, in fact mandatory, to wake up and everyone already knows what they have to do before going to school.

That's why we understood that it was an audience that would give us more information for the research. The interesting thing is that in a way we feel like everyone's integrity, they felt important because they were part of a new process, unknown, but with strong interests in knowing what it is about. As stated in the chart below.

Table 3. Planning of Portuguese Language Classes

Do students give suggestions for the teacher to plan the Portuguese language class?

\begin{tabular}{l|ll}
\hline Yes & 44 \\
\hline No & & 02 \\
\hline \multicolumn{2}{l}{ Source: Search data }
\end{tabular}

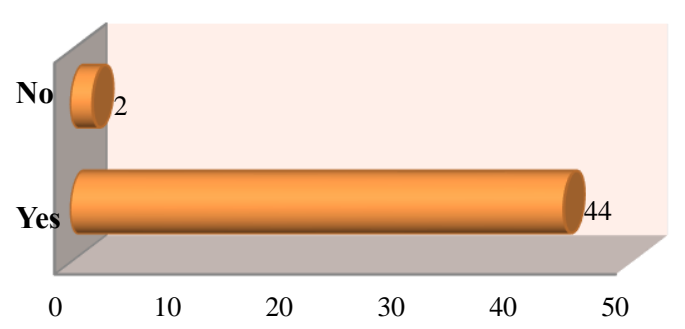

Figure 3. Suggestions for the planning of Portuguese language classes. Source: Search data

We noticed during the research this curiosity of them once they read each question and came the doubts and the question then: what is this?, When they did not understand the context and even a few words, and their concern for the 
research made us grateful that we were there developing this work, we understood that we were on the right path and with the right audience for an achievement that we decided to aim for: to study this part of Brazil, which is called the field and in particular this development that happens and that transforms the being into social actors of its own history.

In fact, being a social actor and builder of your identity and history is a strong and timely point to be worked on in the education of the field. The daily experience makes the awakening of the student grow in the midst of his responsibilities to himself, to the family and the community in which he is inserted.

It was perceived a special care with each material used by the teachers in this teaching process, considering that the student house also commits to this valorization of these materials, are activities performed with instruments, often recyclable, easy access to the luando and still some of them worked, made by the students and teachers themselves. Let's look at the confirmation in the following chart.

Table 4. Materials used in the classroom

Does the Portuguese language material used in the classroom value the reality/experience of the day-to-day life of the student? If so, in what way?

\begin{tabular}{l|r}
\hline Yes & 43 \\
\hline No & 03 \\
\hline
\end{tabular}

Source: Search data

Questioning the above question. If so, in what way? (Conversation with the interviewees, systematized by the interviewers).

"The teacher uses things that we see in our homes, material that the parents of us work from day to day. These are very interesting things. Sometimes they bring together all the classes of the school and agent does work together" 5 th grader"

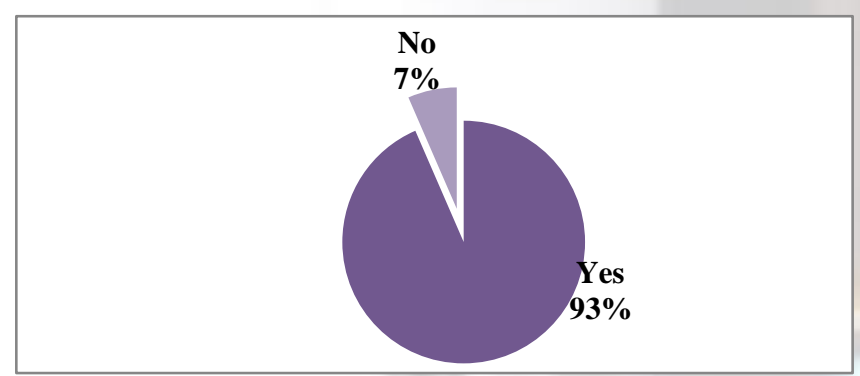

Figure 4. Use of materials in students' daily surveys and experiences. Source: Search data

It is also worth mentioning that we find, especially in the field, school in poor working conditions, that is, lame for the student's learning to occur. We are aware that the space in which the student is inserted is of paramount importance for this psychosocial growth, since it directly influences experiences and personal values, it is important to be and/or be valued, clean, organized, etc., but these oversights are much greater on the part of the public administration, since it has no interest in this type of education, for many it is a part of Brazil that should not be taken into consideration as urban centers, are often taxed for the poor, matutos and anything for this mass of people is already good.

Another point that weakens the education of the field is when in the exchanges of governments, the teachers of the field are invited to teach in the city and those from the city to the countryside, perhaps political persecution, and with this are skills and skills used in opposite spaces, because not always those who live in the city have enough skills to lead a classroom in the field.

Of course, it is easier and less laborious to practice the constant use of a textbook to seek empirical knowledge of students and/or community.

However, this was not exactly what we observed and found in the school field of research, in addition to the teachers living in the field, they experience the education of the field with emphasis on Integrated and Sustainable Local Development - DLIS, this process brings with it the concern of developing an efficient and effective work based on the community cooperatives experienced in the communities, associations, meetings, trade union meetings, etc.

Table 5. Use of other spaces for the contextualization of language classes. Portuguese

To contextualize (give) the class does the teacher use other spaces besides the classroom? If so, in what way?

\begin{tabular}{l|cc}
\hline Yes & 44 \\
\hline No & 02 \\
\hline
\end{tabular}

Source: Search data

If so, in what way? (Conversation with the interviewees, systematized by the interviewers). The teacher uses things that we see in our homes, material that our parents work on a day-to-day basis. These are very interesting things. Sometimes they bring all the classes together and we do work together

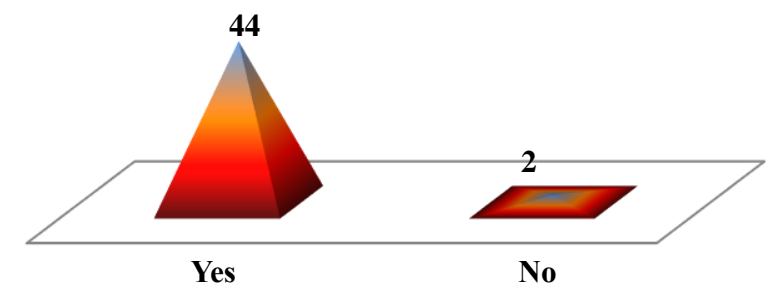

Figure 5. Use of other spaces for the contextualization of language classes. Portuguese countries. Source: Search data

As for the contents, these are worked in the most diversified way possible, are taken into account everything that can create expectation and sharpen the creativity of the student, in a very dynamic way these contents are experienced 
14 Silva, E.P.; Venceslau, M.L.B.; Leão, G.N.; Andrade, J.L.S.; Andrade, I.M. The applicability of Portuguese language teaching in country schools: a case study in the city of Glória do Goitá ...

having starting point and arrival, that is, each of which is worked taking into account the objective that can lead to a better learning and awakening in the student the being critical and the personal and intellectual maturation. As stated in the text below referring to question 6 of the survey questionnaire

"The contents of Portuguese language are worked through texts, research, drawings, stories told about the field, sound, videos, songs that report the history of the man of the field, interviews, dialogues, textbooks etc."

According to the research, the activities experienced in the classroom have several referrals, that is, it never happens in the same way always, there are moments that it is necessary the student is alone, but there are moments that the collective or even the small groups are part of this need felt in the classroom, it is incredible the potential of each student in this construction, and hence not being directly spoken in the construction of writing or reading particularly, but in a procedural and effective construction of learning and opportunity to speak, listening to writing and reading, all this in a very planned way to the point of not opening gaps in this process, that comes or that may impair the significant learning of the student. As the following chart shows.

Table 6. Evaluation of Portuguese language teaching in the classroom How do you evaluate Portuguese language teaching in your classroom? Why is that?

\begin{tabular}{l|c}
\hline Collective & 11 \\
\hline Individual & 06 \\
\hline In group & 29
\end{tabular}

Source: Search data

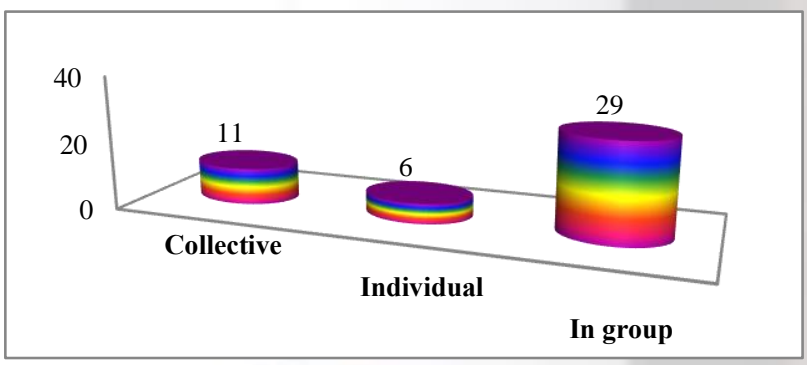

Figure 6. Evaluation of Portuguese language teaching in the classroom. Source: Search data

As we perceived, there are students who answered that they did individual, since they also work the individual, soon caught up to this reference, but in general as confirmed in the graph above, in addition to the three experiences the group activities prevail, because it is a special care for this experience, considering that from the group several discoveries will emerge to ensure the quality of the following meetings.

\section{Conclusions}

Education is not always a flowery field. On the contrary, education is often an arduous, cumrude, painful and difficult process. The true educator cannot be content to be just a conteudist, a transmitter of knowledge. He must exert a warm and positive influence on the students.

After all, educating occurs, therefore, all the time and in a reciprocal way. It occurs as a contingent structural transformation with a history in living together, and the result is that people learn to live in a way that is configured according to the living of the community in which they live. (Souza, 1999. p. 56.)

Education is related to a workshop in which the educator and student work a relationship capable of resulting in instruments that enable the student, at the personal and social level, to exercise his initiative, his freedom and his ability to commit to himself and others. A strong flaw in the formative process of education professionals is the lack of continuing education.

Teachers transmit knowledge only through discourse, "only tell" to students what they have learned or what is in the manuals. In fact, they're narrators of knowledge. But one big question upsets us: When are we going to move on to knowledge builders?

The educator must create spaces, create opportunities for effective participation of the student in the educational process, generating a genuine encounter between educator and student, in the construction of paths and segments for the personal and social development of both.

The school must open itself to various social programs that will contribute to convergent openness with society, after all, one of the objectives of education is to create men capable of doing new things, not simply of repeating what other generations have done - creative, inventive men and discoverers.

Another goal of education is to form minds that can be critical, can verify and not accept what is offered to them. The biggest concern today is slogans, collective opinions, thought tendencies.

We have to be able to resist individually, to criticize, to distinguish between what is proven and what is not. Therefore, we need active social actors who learn early to find things for themselves, partly because of their spontaneous activity and partly for the material we prepare for them and with them; learn early to say what is verifiable and what is simply the first idea that came to them.

In our view the countryside is already keener with your ideas than the schools of the city. Some teachers are already open to new technologies, including alternatives, to improve student learning teaching. They have already realized that it is necessary to value the empirical knowledge of the family, of the child, of the young people of the field from the perspective of a collective and broad construction, which meets and if not, at least stir in the cultures and experiences of the rural/rural. 
[1] ARroyo, M. G. CAlOART, R. S. e Molina M. C. Por uma Educação do Campo. Petrópolis, RJ. Vozes, 2004

[2] ARRUDA. J. O Construtivismo Pós-Piagetiano: novos portes, epistêmicos. Recife: vettores editora. 2001

[3] BAGNO, M. Preconceito Linguístico - o que é e como se faz. $4^{a}$ edição. Ed. Loyola. São Paulo. 1999

[4] BOFF, L. Saber Cuidar. Petrópolis, ed. vozes, 1998

[5] Brasil Secretaria de Educação Fundamental Parâmetros Curriculares Nacionais: Língua Portuguesa. Vol. 2. Brasília. 1997

[6] COSTA, A. C. G. da. Educação e Vida: um guia para o adolescente. $2^{\mathrm{a}}$ edição Belo Horizonte. Modus Faciendi: 2001

[7] Presença e Educação. Ed. Salesiana $2^{\mathrm{a}}$ edição. São Paulo. 2001

[8] O Professor como Educador: um resgate necessário e urgente. Fundação Luís Eduardo Magalhães. Salvador, 2001

[9] Diretrizes Operacionais para a educação básica das escolas do campo. CNE/MEC, Brasília, 2002.

[10] FREIRE, Paulo. À sombra da mangueira. Ed. Olho Dágua. São Paulo. 2001.

[11] KRAMER, S. A Formação do Professor como Leitor e Construtor do Saber: Trabalho apresentado na sessão especial do GT método logra e didática da XVI reunião anual da ANPED caxambu, setembro de 1993.

[12] MOURA, A, de. Princípios e Fundamentos da Proposta de Apoio ao Desenvolvimento Sustentável - PEADS, uma proposta que revoluciona o papel da escola diante das pessoas da sociedade e do mundo. $2^{\mathrm{a}}$ edição. Glória do Goitá - PE, 2003.

[13] NÓVOA, A. Concepção e Prática de Formação Continua de Professores- realidades e perspectivas: Aveiro: universidade de Aveiro, 1991.

[14] PARO, V. Gestão Democrática da Escola Pública. São Paulo; Ática, 1997.

[15] SOUZA, J. F. de. A Educação Escolar, Nosso Fazer Maior, des (a)fia o nosso saber - educação de jovens e adultos. Recife. Bagaço; 1999

[16] TEDESCO, J. C. O Novo Pacto Educativo. São Paulo; Ática, 1998. 